\title{
Co-evolution in Big History: A Transdisciplinary and Biomimetic Approach to the Sustainable Development Goals
}

\author{
Javier Collado-Ruano \\ National University of Education, Ecuador
}

\begin{abstract}
The objective of this paper is to study the co-evolutionary processes that life has developed over billions of years in the context of 'Big History'. The main intention is to identify their operational principles and strategies in order to apply them to solve complex problems as the 'Sustainable Development Goals' (SDGs) proposed by the United Nations for the year 2030. The most important observations show us that all forms of life are developing sustainable and regenerative strategies in nature since life's first appearance about 3.8 billion years ago. As a result of the discussion, those co-evolutionary operational principles of ecosystem cooperation must be bio-mimetically copied, emulated, and improved to reduce ecological footprint and to achieve the SDGs. In conclusion, biomimicry finds in Big History a perfect theoretical model to understand how humanity must coevolve in harmony with nature.
\end{abstract}

\section{INTRODUCTION}

The idea of interconnection between human beings and other life forms leads us to revise the concept of co-evolution through a transdisciplinary study of processes that life has developed on Earth since their appearance some 3.8 billion years ago. For this reason, this article makes a qualitative, exploratory, descriptive, and analytical study that seeks to unify, integrate, and include the history of the Universe, the Solar System, Earth, and Life along with the history of mankind. Big History theoretical framework allows us to understand in a systemic, holistic, and multidimensional mode, our individual and collective responsibility to co-evolve in a resilient and regenerative way on Earth. It means new paths to manage and organize the knowledge to understand the interconnections of Social Evolution \& History, Vol. 17 No. 2, September 2018 27-41 
mankind with the different levels of reality that co-exist in nature and the cosmos at the same time.

The Big History helps us to identify and recognize the sustainable and regenerative strategies that work in nature to inspire us bio-mimetically in solving human problems (social, economic, technological, etc.). The continued exploitation of materials and energy resources of the Earth by the models of production and consumption has caused a great ecological footprint that has been disclosed as unsustainable. In this sense, the transdisciplinary approach allows us to go beyond the concept of sustainable development, a concept very much exploit in recent years by the marketing of 'green' products. While the notion of sustainable development focuses on the minimization of the negative human impact on Earth, the notion of regenerative development focuses on the maximization of positive human impact on Earth (Orr 2002; Pauli 2010; Wahl 2016). In short, a society that walks towards a regenerative culture must learn how to restore nature. Here, Pauli claims that biomimetic approach is the best path to create circular economies:

Highly productive Blue Economy industries, capable of generating employment for all, are on the horizon. They are based on how nature uses physics and biochemistry to build harmoniously functioning whole systems, cascading abundantly, transforming effortlessly, and cycling efficiently without waste or energy loss. These forces not only determined the parameters of life on Earth but also helped shape life itself. As we move from a linear perception to seeing a cyclic, regenerative model, we too can shape our behaviors and practices to assure that everyone's basic needs are met and that our blue planet Earth, with all its inhabitants, progresses towards an optimum future (Pauli 2010: 11-12).

Instead of exploiting the natural resources of our planet with outdated linear perception, the achievement of the Sustainable Development Goals (SDGs) need to be biomimetically inspired to solve the environmental, economic, political, and social challenges. Nature provides lessons in survival, resilience and coevolution, as well as sophisticated diversification strategies that have been proven in a constant process of trial and error developed in about 3.8 billion years. Designing our cultures with the inherent wisdom of nature is the most efficient way to re-establish a creative fit between humanity and nature. Promoting biomimetic innovations for a regenerative culture is a historic opportunity to achieve the SDGs led by the United Nations for the year 2030. Current global civilization is characterized for the socio-ecological problems that transcend national borders. 
Hence the need to transgress the current planetary crisis with the new transdisciplinary approach that Big History gives us, because it represents an epistemic tool that conceived the interrelationships of the human condition in its cosmic and earthly context. The transdisciplinary approach allows us to include human cultural systems and natural ecosystems within the co-evolutionary historical process. If we want to co-evolve in Gaia ${ }^{1}$ harmonically to achieve the SDGs, we must learn how to reintroduce our sociosphere and technosphere into the biosphere (Collado-Ruano 2015).

\section{METHODOLOGY}

This paper combines transdisciplinary methodology with the biomimetic approach to innovate in the field of Big History research. Biomimicry seeks regenerative solutions to human complex challenges by emulating nature's time-tested patterns and strategies. The achievement of the SDGs could find many regenerative and resilient solutions by the imitation of the models, systems, and elements of nature. Biomimicry finds in Big History a perfect theoretical model to understand the humanity's crisis challenge: by raising awareness about the cosmic exception that biodiversity on Earth represents in the whole universe. While Big History contextualizes us in nature and the whole cosmos, biomimicry emerges as a new science that considers values of nature as a model, measure, and mentor: looking for inspiration and imitation of natural processes to be applied into social systems, and thus finding innovative solutions to complex problems such as the SDGs.

The term biomimicry comes from the ancient Greek ßíos (bios), life, and $\mu$ í $\mu \eta \sigma \varsigma$ (mìmèsis), imitation. In the nineties, Janine Benyus popularized this term in her book 'Biomimicry: Innovation Inspired by Nature'. Since then, biomimetic approach is one of the most innovative responses in recent years to protect the environment and improve the quality of life through new sustainable habits of consumption and production. 'Biomimicry uses an ecological standard to judge the correctness of our innovations. After 3.8 billion years of evolution, nature has discovered what works, what is appropriate, and what endures', notes Benyus (2012: 13), affirming that biomimetic revolution 'begins an era based not on what we can extract from the natural world, but what it can teach us'. This scientific line of thought is in harmony with ancient worldview of indigenous and aborigines peoples, who see the sacred dimension in nature. So the concept of biomimicry originates to the first human groups that created gods according to various natural phenomena (sun, water, ray...). Biomimicry revives the sacred and our spiritual intelligence (Zohar and Marshall 2000). That is why science and spirituality converge within the biomimetic vision. 


\section{A BRIEF SUMMARY OF HUMAN CO-EVOLUTION ON EARTH}

According to the scientific consensus of Big History, the humanly known universe arose about 13.7 billion years before present (BP), with the explosion of the Big Bang. The Earth formation occurred between 5 and 4.5 billion years BP, and the miracle of life appeared around 3.8 and 3.5 billion years BP (Margulis 1998). During the first half of this period, the forms of first-born life on Earth remained at very simple complexity levels (as Archaebacteria or Eubacteria), but the appearance of free oxygen in the atmosphere triggered the emergence of the first complex cells (Eukaryotes), some 2 billion years BP (Spier 2011). The Cambrian explosion of metazoans took place about 1.5 billion years later, some 542 million years BP. Since then, the biological variety has increased rapidly, forming a wide range of multicellular organisms that develop survival strategies with very unique energy flows, such as the food chain.

While it seems that life arose in the depths of the oceans, it only managed to reach the mainland about 450 million years BP. Only 250 million years after reaching the Earth's surface came the first warmblooded animals, where dinosaurs highlighted during the Cretaceous period until they disappeared 66 million years ago by a supposed asteroid impact on Earth. As historian David Christian (2010: 162) noted, this circumstance gave rise to hegemonic period of mammals, from where the first bipedal hominids emerged around 7 million years BP. Thanks to carbon-14 testing performed on fossil remains found to date, we can learn in an approximate way the dating of first Australopithecus, which seem to be about 4 million years. Homo Habilis dates from 2.5 until 1.9 million years, those of Homo erectus are around 1.9 million years, and those of Homo neanderthalensis and Homo sapiens point about 200,000 years ago. With the extinction of Homo floresiensis about 13,000 years ago, Homo sapiens is the only survivor of the human species that co-inhabits and coevolves on planet Earth with the rest of the animal biodiversity, plants, insects, bacteria, etc.

Co-evolution is a term coined by the biologist Paul Ehrlich and the botanist-environmentalist Peter Raven in 1964. In their joint work 'Butterflies and Plants: A Study in Coevolution', they approached the reciprocal evolutionary influences of plants and insects that feed on them: 'an approach to what we would like to call coevolution is the examination of patterns of interaction between two major groups of organisms with a close and evident ecological relationship, such as plants and herbivores' (Ehrlich and Raven 1964: 586). While the idea of co-evolution was not new and had been already expressed in previous theories, the use made for Ehrlich and Raven allowed thinkers from other fields of application make new interpretations. In 1980, evolutionary ecologist Daniel Janzen was the first to define 
the concept of coevolution in his paper 'When Is It Coevolution?' "“Coevolution" may be usefully defined as an evolutionary change in a trait of the individuals in one population in response to a trait of the individuals of a second population, followed by an evolutionary response by the second population to the change in the first', Janzen (1980: 611) explains adding that " diffuse coevolution" occurs when either or both populations in the above definition are represented by an array of populations that generate a selective pressure as a group'. Thus, ecological interdependence requires three basic principles: 1) specificity, where the evolution of each species is due to the selective pressures of the other; 2) reciprocity, when both species jointly evolve; 3 ) simultaneity, both species evolve simultaneously. So the co-evolutionary process has been used in a relatively restricted sense in the context of biological evolution.

But the sense of 'coevolution' used in this research goes beyond the discussion about sustainability: including both the degree of mutual phylogenetic partnership as the degree of mutual change in the co-adaptation, but also global processes of macroevolution and specific processes of microevolution. Coevolution is defined, then, as a reciprocal evolutionary change among species and their natural environment that, during the complex development of inter-retro-actions with each other, mutually modify each other constantly. This view is in harmony with the distinction between biological and social evolution introduced by historians Andrey Korotayev, Alexander Markov, and Leonid Grinin (2015). Coevolution is a widespread in nature feedback process which became the basis for agricultural and industrial exploitation of human beings in their historical evolution on Earth. As explained by ecological economist Richard Norgaard (1994: 39): 'with industrialization, social systems coevolved to facilitate development through the exploitation of coal and petroleum. Social systems no longer coevolved to interact more effectively with environmental systems'. With Industrial Revolution, there began an era of hydrocarbons that drastically changed co-evolutionary processes of the prior agricultural stage of mankind (Lovelock 1988). When social systems began to exert strong pressure on environmental systems, the stock of energetic and material resources decreased very quickly: starting an evolutionary period of planetary unsustainability. That is why SDGs are so important in Big History. Human race has had a profound impact on the climate and environment of the Earth and the SDGs represent our last opportunity to avoid ecological extinction and points of no return in the new geological era we have entered - the Anthropocene.

\section{ANTHROPOCENE: HUMAN FOOTPRINT ON EARTH}

In the last years, the term 'Anthropocene' has become an important topic in scientific, philosophical, and academic debates. Scientists divide the 
history of our planet into epochs, and we are currently living in the Holocene epoch, a name given to the post-glacial geological period of the past ten to twelve thousand years. However, there is a global debate questioning the huge ecological footprint left by humankind on the Earth. The biologist Eugene Stoermer and the Nobel winning chemist Paul Crutzen advanced the term 'Anthropocene' in 2000, and it has gained acceptance as a new geological period characterized by the influence of human behavior on Earth's atmosphere. Using atmospheric carbon dioxide concentration as a simple indicator to track the pollution acceleration, many researches have proved that our human activities have experienced a great explosion with significant consequences for Earth System functioning. According to Steffen, Crutzen, and McNeil (2007), the Anthropocene began around 1800 with the onset of industrialization, the central feature of which was the enormous expansion in the use of fossil fuels. Then, the concept emphasizes the humankind influence in global geology and ecology, when human actions have a drastic effect on the Earth.

Therefore, the globalized society of the twenty-first century must become aware, urgently, of socioeconomic unsustainability of 'four-engineof-globalization': science, industry, capitalism, and technology (Morin, Roger and Motta 2003: 104). Despite all benefits they have given to humanity, they are seriously jeopardizing both future human generations and the rest of natural ecosystems. Physicist Basarab Nicolescu (2014) claims for transdisciplinary knowledge to understand that our species' evolution is intrinsically interlinked with constant co-evolution processes that different life forms are developing on our planet Earth from billions years ago. It is a multidimensional coevolution that unfolds through interretro-actions between different levels of cosmic, planetary, regional, national, and local reality, where an extensive network of universal interdependence is established with ecological, biophysics, social, political, cultural, economic, and technological phenomena. Hence the uncontrolled exploitation of natural resources for the manufacture of industrial products has become an issue of great concern at global level. That is why the SDGs were created.

In this Anthropocene context, biomimicry emerges as a transdisciplinary science that deals with studying the complexity of inter-retro-actions developed between dynamic systems that make life (humans, animals, plants, etc.), within an environment which houses the ideal conditions for coevolution. Mankind is the unique species that participates in a cosmic dance starred by matter-energy phenomena whose symphony reminds us that we are active players in the coevolution of a common world shared with ecosystems of Gaia. 'We now recognize the Earth as a single selfcreative being who came to life in its rotating dance around the space' says biologist and futurist Elisabet Sahtouris (1998: 25-26), adding that 
'as we gather the scientific details of the dance of life on our planet (...), the evolution of our species takes a new meaning in relation with the whole'. Hence the systematic degradation of nature makes us accomplices of a global ecocide, since the ecological footprint (Wackernagel and Rees 1996) is perpetuated by our active participation in consumerist dynamics and our bioethics passivity before the destruction of life on our planet Earth, which is our sacred common good. 'There are few more alarming indicators about the brutal climate imbalance that we have implemented, and the consequences will be terrible (ecocide and genocide, if you want to express in a synthetic formula)', argues the philosopher Jorge Riechmann (2014: 333). Our common future is built today and we cannot fail to future generations.

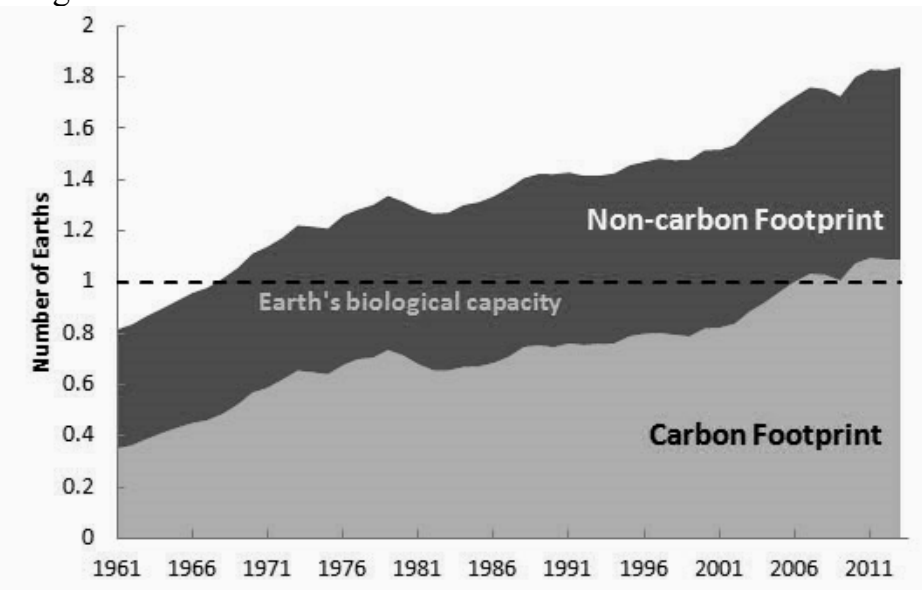

Fig. 1. Ecological Footprint. Resource: Global Footprint Network ${ }^{2}$

According to the Worldwatch Institute (2006), China, USA, India, Japan and the European Union are using 75 per cent of total biocapacity. The other countries only have 25 per cent of the planet's biocapacity to develop. With this unequal development between called global North and global South, we all have overpassed the biophysical limits of Earths' regeneration. This means we are using the natural resources of future generations. They will suffer the climatic consequences of global warming caused by our current consumer culture (chronic shortage of resources, ecosystem changes, loss of biodiversity, glacier melting, rising sea level, deforestation, pollution of soil, water and air, etc.). But this kind of 'planetary apartheid' and irrational progress becomes more impressive when we read the last information from OXFAM (2016: 2), because 'the richest one per cent of the world population has more wealth than the remaining 99 per cent (...). In 2015, only 62 people have the same wealth that 3,600 million people (the poorest 
half of humanity)'. There are 836 million people with $\$ 1.25$ per day, concentrated in South Asia and sub-Saharan Africa (UN 2015: 4). With such imbalances, biomimicry represents a paradigmatic shift because its regenerative vision goes beyond of traditional conception of development.

From a cosmodern vision, I propose that the existing debate on SDGs does not have to find solutions for the increasingly complex problems that arise in the current economic system of the world-society of the third millennium. SDGs should promote the transformation of capitalist production system inspired by biomimicry approach. Affirming that economic growth is good for itself as well as postulating that human quality levels can be measured by GDP and GNP of a country, represent an intellectual fraud of danger consequences in the era of global ecological crisis (Stiglitz, Sen, and Fitoussi 2010). While it is true that capitalist system has brought enormous material benefits, its functionalist view subordinates everything to the maximum economic profit and the indiscriminate consumption at the expense of nature. It does not work to debate between communism, anarchism, socialism, capitalism or any other political theory of social organization derived from classical mechanics mental structures (where there is just one level of reality), but to mimic our own nature. 'If we want to get along with Gaia, it is precisely how we must see ourselves, as one vote in a parliament of thirty (or perhaps even a hundred) million seats, a species among species' (Benyus 2012: 24). Why does the human species continue mortgaging the future of millions of species by its absurd logic of irrational consumption, which involves the exploitation of natural resources? Why do we believe in the epistemological illusion of unlimited economic growth when it has never existed any living species in nature, which grow endlessly to infinity? How could biomimicry approach inspire us to achieve the SDGs?

\section{BIOMIMETICS: A BIOINSPIRING WORLDVIEW}

Human irrationality in patterns of consumption and production are unsustainable and are also causing serious consequences in the environment: climate change, desertification, destruction of natural resources, pollution of water and air, global warning, etc. In this sense, this paper reclaimed the principle of biomimicry as a meta-model to be applied in economy, engineer, architecture, design, urbanism, industry, technology, art, politics, education, energy, and so on (Collado-Ruano 2017). Nature is the only 'business company' that has never failed after 3.8 billion years. To (re)design regenerative cultures, it is necessary to understand better the principles and strategies of nature. In this sense, Table 1 shows a comparison between some contemporary thinkers who have proposed to learn from nature to build a resilient society. 
Table 1

Comparison of nature principles proposed by Commoner (1971), Capra (1998), Benyus (2012), and Riechmann (2014)

\begin{tabular}{|c|c|c|c|c|}
\hline $\begin{array}{l}\text { Author / } \\
\text { Principle }\end{array}$ & $\begin{array}{c}\text { Barry } \\
\text { Commoner }\end{array}$ & $\begin{array}{l}\text { Fritjof } \\
\text { Capra }\end{array}$ & Janine Benyus & $\begin{array}{c}\text { Jorge } \\
\text { Riechmann }\end{array}$ \\
\hline $1^{0}$ & $\begin{array}{l}\text { Everything is } \\
\text { connected to } \\
\text { everything } \\
\text { else }\end{array}$ & $\begin{array}{l}\text { Interdepend- } \\
\text { ence }\end{array}$ & $\begin{array}{l}\text { Nature runs on } \\
\text { natural sunlight }\end{array}$ & $\begin{array}{l}\text { Homeostasis in } \\
\text { biophysics } \\
\text { terms }\end{array}$ \\
\hline $2^{\circ}$ & $\begin{array}{l}\text { Everything } \\
\text { must go } \\
\text { somewhere }\end{array}$ & $\begin{array}{l}\text { Cyclical na- } \\
\text { ture of eco- } \\
\text { logical pro- } \\
\text { cesses }\end{array}$ & $\begin{array}{l}\text { Nature uses only } \\
\text { energy and re- } \\
\text { sources that it } \\
\text { needs }\end{array}$ & $\begin{array}{l}\text { Living from } \\
\text { sun as energy } \\
\text { resource }\end{array}$ \\
\hline $3^{\circ}$ & $\begin{array}{l}\text { Nature knows } \\
\text { best }\end{array}$ & $\begin{array}{l}\text { Tendency to } \\
\text { associate }\end{array}$ & $\begin{array}{l}\text { Nature fits form to } \\
\text { function }\end{array}$ & $\begin{array}{l}\text { Close material } \\
\text { cycles }\end{array}$ \\
\hline $4^{0}$ & $\begin{array}{l}\text { There is no } \\
\text { such thing as } \\
\text { a free lunch }\end{array}$ & Flexibility & $\begin{array}{l}\text { Nature recycles } \\
\text { and finds uses for } \\
\text { everything }\end{array}$ & $\begin{array}{l}\text { Not carrying } \\
\text { too far the } \\
\text { materials }\end{array}$ \\
\hline $5^{\circ}$ & & Diversity & $\begin{array}{l}\text { Nature rewards } \\
\text { cooperation }\end{array}$ & $\begin{array}{l}\text { Avoiding xe- } \\
\text { nobiotics }\end{array}$ \\
\hline $6^{\circ}$ & & & $\begin{array}{l}\text { Nature depends on } \\
\text { and develops di- } \\
\text { versity }\end{array}$ & $\begin{array}{l}\text { Respecting } \\
\text { diversity }\end{array}$ \\
\hline $7^{0}$ & & & $\begin{array}{l}\text { Nature requires } \\
\text { expertise and re- } \\
\text { sources }\end{array}$ & \\
\hline $\mathbf{8}^{\circ}$ & & & $\begin{array}{l}\text { Nature avoids in- } \\
\text { ternal excesses }\end{array}$ & \\
\hline $9^{\circ}$ & & & $\begin{array}{l}\text { Nature taps into } \\
\text { the power of limits }\end{array}$ & \\
\hline
\end{tabular}

As different authors have postulated, the principle of biomimicry is already articulated enough to be a tool which guide us towards achieving a regenerative development in co-evolutionary harmony with Gaia. By identifying the operational principles of live at different levels, and more specifically in its ecosystem level, we can design 'other possible worlds' where human systems are melodically engaging in the co-evolutionary symphony that takes place in the Big History. In 1971, the biologist and ecologist Barry Commoner formulated the basic 'laws' of ecology: 1) Everything is connected to everything else. There is one ecosphere for all living organisms and what affects one, affects all. 2) Everything must go somewhere. There is no 'waste' in nature and there is no 'away' to which things can be thrown. 3) Nature knows best. Humankind has fashioned technology to improve upon nature, but such change in a natural system is likely to be detrimental to that system. 4) There is no such 
thing as a free lunch. Exploitation of nature will inevitably involve the conversion of resources from useful to useless forms. In his later book 'Making Peace with the Planet', Commoner (1990) notes that technosphere prevalent in industrialized societies 'is in war' with the biosphere, causing global ecologic crises impossible to be hidden.

The notion of 'ecoliteracy' or 'ecological literacy' developed by physicist Fritjof Capra seeks to understand the organizational principles of ecosystems to build sustainable human communities. According to Capra (1998), there are five main principles: 1) Interdependence; 2) Cyclical nature of ecological processes; 3) Tendency to associate, establish links and cooperate as essential characteristics of life; 4) Flexibility; 5) Diversity. In short, Capra (1998: 20) argues that 'understanding the life must be seen as the scientific vanguard of the paradigm shift, from a mechanistic world conception through an ecological conception', postulating that human systems should be governed by the key criteria of a living system: a) organizational pattern or configuration of relationships that determinate the essential characteristics of the system; b) structure or physical embodiment of the organizational pattern of the system; c) vital process or involved activity in the continuous physical embodiment of the organizational pattern of the system (Capra 1998: 175). In other words, Capra (1998) believes reconnecting with the web of life means rebuilding and maintaining regenerative communities. For this task we can learn a lot from ecosystems, true resilient communities of plants, animals, and microorganisms. To understand them, we must become ecologically literate. 'Being ecologically literate, being "ecoliterate", means understanding the organizing principles of ecological communities (ecosystems) and use these principles to build sustainable human communities. We need to revitalize our communities including education, business, and policies (Capra 1998: 307)'.

In this literacy context, Janine Benyus claims that 'biomimicry' approach uses Nature as model, measure, and mentor. According to Benyus (2012), Nature as model is viewed as the poetic principle of biomimetics because it tells us how the things are to be 'brought forth'. Nature as a measure is seen as the ethical principle of biomimetics because it tells us how Nature respects its biophysical limits of regeneration and how we may emulate them. And Nature as mentor is watched as the epistemological principle of biomimetics because it tells us Nature is the ultimate source of wisdom and truth (Collado-Ruano 2018). The natural world has designed co-evolutionary strategic processes that work and persist over billions, so it represents the best meta-model to imitate, copy, emulate, and perfect our cultural models of development (Collado-Ruano 2016).

In this line of thought, Benyus (2012) recognized nine laws, strategies, and operational principles of Life in the Nature that can be used as 
example of beneficial model for human behavior: 1) Nature runs on natural sunlight; 2) Nature uses only energy and resources that it needs; 3) Nature fits form to function; 4) Nature recycles and finds uses for everything; 5) Nature rewards cooperation; 6) Nature depends on and develops diversity; 7) Nature requires expertise and resources; 8) Nature avoids internal excesses; 9) Nature taps into the power of limits. Those principles invited us to reflect and compare the inherent characteristics of ecosystems with the culture of human production. 'It could even be said that capitalism is the metaphorical antithesis of the natural process of life: in it prevails exclusion, squander, deregulation, what we call today as relocations, as well as unaware speculative flows to real production of goods and services' notes the natural philosopher Luciano Espinosa (2007: 66) compared to natural systems of the biosphere where 'operate inclusive circuits of all members of the network, which are attached to the ground, tied to the satisfaction of the basic needs and the constant recycling of matter and energy'. In short, biomimetics allow us to rebuild human systems in order to fit them in the natural systems, where the whole is co-evolving harmonically.

In a similar manner, the economist Jorge Riechmann (2014: 211) suggests six basic principles for the ecological reconstruction of economy: 1) Homeostasis or 'steady state' in biophysics terms; 2) Living from sun as energy resource; 3) Close material cycles; 4) Not carrying too far the materials; 5) Avoiding xenobiotics as POPs (Persistent Organic Pollutants), GMO (Genetically Modified Organisms); 6) Respecting diversity. Riechmann (2014) defines the concept of economic homeostasis to stop economic growing and to focus more on qualitative development. At the same way as there is no living species in nature which grow all time, the economy (as subsystem of Gaia) must steady, only consume necessary natural resources and focus on human capabilities in a broaden sense. This means stop using the GDP and GNP as a compass to guide progress, because they do not take into account the number of hours that parents devoted to their children, or insecurity in the streets, or the quality of education, quality health systems, etc.

In other words, all countries with a high GDP have destroyed the environment, as has been the case of China or Taiwan in the last years. 'Ecological Theory describes how biotic communities go for a process of development (or ecological succession) from youth to maturity (or climax)' notes Riechmann (2014: 212), adding

the interesting thing for us is that this maturity state is characterized by stability, decrease of net production of biomass (more energy is consumed in respiration), decrease of entropy, complexity (increased information), closing cycles of minerals, increased nutrient conservation, and increasing the global efficiency in the use of energy and nutrients. 
Then, it does not seem unreasonable to derive - by biomimicry from the maturity ecosystem concept, the idea of economic homeostasis or steady state (in biophysical terms) to human systems. A new regenerative paradigm emerges from all those ecological principles recognized by many authors. I argue that Big History constitutes the requisite ground for a new biomimetic era in the Anthropocene, which I call 'Cosmodernity' (Collado-Ruano 2018). This idea is in full harmony with Nicolescu (2014) and Moraru (2011), and it seeks to involve and innovate various socioecological areas for the achievement of the SDGs (i.e. biotechnology, bioengineering, biotextile, bioarchitecture, biomedicine, bioeconomy, etc.).

\section{CONCLUSIONS: LEARNING TO CO-EVOLVE IN COSMODERNITY}

Obviously, all these ecological principles mentioned above do not tell us what Nature is, they just tell us about certain key aspects of the human relationship with Nature. This is the main reason we must learn to coevolve between the constant processes of material and energetic restructuration of nature. Then, the achievement of the SGDs involves using the creativity of nature to (re)design regenerative cultures. In other words, we need to create transcultural bridges between all societies, without hierarquizing any culture our episteme among others. This implies going beyond rational and scientific approach to include decolonial vision, where arts, emotions, spirituality, indigenous wisdom, and ancestral beliefs are essential dimensions to (re)design regenerative paths of development. For this reason, transdisciplinary and biomimicry approach is required in the field of Big History research, in order to create an 'ecology of knowledge' that is in, between, and beyond scientific and academic disciplines (Nicolescu 2008; Santos 2009).

In recent decades, applying a transdisciplinary approach has become an important epistemic tool to face socio-ecological challenges. Many great contemporary thinkers, philosophers, scientists, and artists argue that our spiritual deficit is the main cause of the ecological footprint that humankind left in our sacred Mother Earth (Hathaway and Boff 2014). In this sense, the Cosmodernity paradigm is defined by Collado, Galeffi, and Ponczek (2014) as the civilizational metamorphosis where humans reinvent their relationship with the sacred. This means stop exploiting nature to learn from it and create new biomimetic models that allow us to (re)design regenerative cultures. Unlike the Industrial Revolution, the Biomimetic Revolution involves the appearance of a new epistemological paradigm that focuses on what we can learn from nature, rather than focusing on what we can exploit it to obtain raw materials to be manufactured in the industry. From this cosmodern perspective, biomimicry can be defined as the transversal study of self-eco-organization of biological systems in their environ- 
ment, in order to discover the co-evolutionary principles and strategies that occur in Gaia to take them as a meta-model to imitate in human sub-models.

Biomimicry is a meta-model that seeks to transform paradigmatic crossroads at which we are now through imitation of the creative processes that have been inherent in the wisdom of nature. It is an epistemic tool that facilitates the civilizational change course to restore biodiversity and the achievement of the SDGs. Biomimicry shows us that continued material growth is unsustainable and invites us to conceive the universe with a holistic, relational, contextual, and participatory thinking. According to Benyus (2012: 16), 'living things have done everything we want to do, without guzzling fossil fuel, polluting the planet, or mortgaging their future. What better models could there be?' In this direction, we must learn from ecosystem processes that are co-evolving in the Big History to copy them, imitate them, and perfect them with the main goal to face the SDGs' challenges.

Consequently, biomimicry also represents a (r)evolution of human knowledge because it leaves behind centuries of efforts to dominate and control nature. An idea that has always been present in the ancestral worldviews of indigenous and aboriginal peoples, who defended Mother Earth as a living organic system (Acosta 2013), and not as a dead entity that only provides us with raw materials for manufactures. Hence, the adjacent transdisciplinary character in biomimicry, whose ecology of scientific and non-scientific knowledge creates an epistemic meta-model that opens the doors for a regenerative development on a planetary scale. For this reason, many scientists return to study all those epistemologies that advocate to rescue and defend all living and non-living organism of nature above economic gain imposed by the dominant globalization. It is obvious that biomimicry is not a new idea, since humans have always looked to nature for answers to solve complex and simple problems of our existence on Earth. Biomimicry represents a theoretical-pragmatic symbiosis between citizens from the North and the South, and also a fundamental tool to achieve the SDGs. Let us address to Big History to learn how to co-evolve harmonically as cosmodern civilization. Are you ready? I invite all readers to explore and discuss more ideas concerning the topics of this paper.

\section{NOTES}

${ }^{1}$ Gaia is the primal goddess personifying the Earth in Greek mythology.

${ }^{2}$ https://www.footprintnetwork.org/our-work/climate-change/.

\section{REFERENCES}

Acosta, A. 2013. El Buen Vivir. Sumak Kawsay, una oportunidad para imaginar otros mundos. Barcelona: Icaria. 
Benyus, J. 2012. Biomímesis. Cómo la ciencia innova inspirándose en la naturaleza. Barcelona: Tusquets editores.

Capra, F. 1998. La trama de la vida. Una nueva perspectiva de los sistemas vivos. Barcelona: ANAGRAMA.

Christian, D. 2010. Mapas del tiempo: Introducción a la Gran Historia. Barcelona: Crítica.

Collado-Ruano, J. 2015. Biomimicry: A Necessary Eco-Ethical Dimension for a Future Human Sustainability. Future Human Image 2: 23-57.

Collado-Ruano, J. 2016. Paradigmas epistemológicos en Filosofia, Ciencia y Educación. Ensayos Cosmodernos. Saarbrüken: Editorial Académica Española.

Collado-Ruano, J. 2017. Learning to co-evolve in the Anthropocene: Philosophical Considerations from Nature. Azimuth. International Journal of Philosophy, n. 9, pp. 17-30.

Collado-Ruano, J. 2018. Cosmodern Philosophy: Transdisciplinary Refelctions on Nature, Science, and Religion. Ilu. Revista de Ciencias de las Religiones 23, 57-80.

Collado-Ruano, J., Galeffi, D., and Ponczek, R. 2014. O paradigma da cosmodernidad: uma abordagem transdisciplinar à Educação para a Cidadania Global proposta pela UNESCO. Revista da FAEEBA: educação e contemporaneidade, Salvador 42 (23): 141-152.

Commoner, B. 1971. The Closing Circle: Nature, Man, and Technology. New York: Knopf.

Commoner, B. 1990. Making Peace with the Planet. New York: Pantheon.

Ehrlich, P., and Raven, P. 1964: Butterflies and Plants: A Study in Coevolution. Society for the Study of Evolution 4 (18): 586-608.

Espinosa, L. 2007. La vida global (en la eco-bio-tecno-noo-sfera). LOGOS: Anales del Seminario de Metafisica 40: 55-75.

Hathaway, M., and Boff, L. 2014. El Tao de la liberación. Una ecología de la transformación. Madrid: Trotta.

Janzen, D. 1980. When Is It Coevolution? Evolution 34 (3): 611-612.

Korotayev, A. Markov, A., and Grinin, L. 2015. Modeling of Biological and Social Phases of Big History. In Grinin, L., Korotayev, A. (ed.), Evolution. From Big Bang to Nanorobots (pp. 111-150). Uchitel: Publishing House.

Lovelock, J. 1988. Ages of Gaia. Oxford: Oxford University Press.

Margulis, L. 1998. Symbiotic Planet: A New Look at Evolution. New York: Basic Books.

Moraru, C. 2011. Cosmodernism: American Narrative, Late Globalization, and the New Cultural Imaginary. Ann Arbor: The University of Michigan Press. 
Morin, E., Roger, E., and Motta, R. 2003. Educar en la era planetaria. Barcelona: Gedisa.

Nicolescu, B. 2014. From Modernity to Cosmodernity. Science, Culture, and Spirituality. New York: SUNY.

Norgaard, R. 1994. Development Betrayed. The End of Progress and a Coevolutionary Revisioning of the Future. New York: Routledge.

Orr, D. 2002. The Nature of Design. Ecology, Culture, and Human Intention. Oxford: Oxford UniversityPress.

OXFAM. 2016. Una economía al servicio del $1 \%$. Acabar con los privilegios y la concentración de poder para frenar la desigualdad extrema. OXFAM report $\mathrm{n}^{\circ} 210$.

Pauli, G. 2010. The Blue Economy. 10 years, 100 innovations, 100 million jobs. Taos: Paradigm Publications.

Riechmann, J. 2014. Un buen encaje en los ecosistemas. Madrid: Catarata.

Sahtouris, E. 1998. A Dança da Terra. Sistemas vivos em evolução: uma nova visão da biología. Rio de Janeiro: Rosa dos Tempos.

Santos, B. 2009.Una epistemología del sur. México: Siglo XXI.

Spier, F. 2011. Big History and the Future of Humanity. Oxford: Blackwell.

Steffen, W., Crutzen, P., and McNeill, J. 2007. TheAnthropocene: Are Human Now Over whelming the Great Forces of Nature? AMBIO: A Journal of the Human Environment, 36 (8): 614-621.

Stiglitz, J., Sen, A., and Fitoussi, J. 2010. Mis-Measuring Our Lives. Why GDP Doesn't Add Up. The Report by the Commission on the Measurement of Economic Performance and Social Progress. New York: New Press.

United Nations. 2015. Transforming our World: The 2030 Agenda for Sustainable Development. Resolution adopted by the General Assembly on 25 September 2015. New York: UN.

Wackernagel, M., and Rees, W. 1996. Our Ecological Footprint. Reducing Human Impact on the Earth. Gabriola Island: New Society Publishers.

Wahl, D. 2016. Designing Regenerative Cultures. Axminster: TriarchyPress.

Worldwatch Institute. 2006. State of the World 2006. Special Focus: China and India. Washington: Island Press.

WWF - World Wildlife Fund. 2014. Living Planet Report 2014. Species and Spaces, People and Places. World Wildlife Fund.

Zohar, D., and Marshall, I. 2000. SQ: Spiritual Intelligence. The Ultimate Intelligence. Connecting with our Spiritual Intelligence. London: Bloomsbury Publishing. 